\title{
Conjoint Effect of Oil-Seed Cakes and Pseudomonas fluorescens on the Growth of Chickpea in Relation to the Management of Plant-Parasitic Nematodes
}

\author{
Rose Rizvi*, Irshad Mahmood, Sartaj A Tiyagi and Zehra Khan \\ Section of Plant Pathology and Nematology; Department of Botany; Aligarh Muslim University; Aligarh - 202002
} (U.P.) India

\begin{abstract}
Soil application of organics has been explored as an alternative means of organic management of plant-parasitic nematodes. Efficiency of different oil-seed cakes of neem (Azadirachta indica), castor (Ricinus communis), groundnut (Arachis hypogaea), linseed (Linum usitatissimum), sunflower (Helianthus annuus) and soybean (Glycine max) were evaluated in field conditions with association of Pseudomonas fluorescens in relation to growth parameters of chickpea and population of plant-parasitic nematodes. Their efficacious nature was highly effective in reducing the population of these dominant soil nematodes. Significant improvement was observed in plant-growth parameters such as plant weight, percent pollen fertility, pod numbers, root-nodulation and chlorophyll content of chickpea, seemed to be due to reduction in disease incidence and might be due to growth promoting substances secreted by $\mathrm{P}$. fluorescens. The multiplication rate of nematodes was less in the presence of $\mathrm{P}$. fluorescens as compared to its absence. Most effective combination of $\mathrm{P}$. fluorescens was observed with neem cake.
\end{abstract}

Key words: chickpea; oil-seed cakes; organic management; plant-parasitic nematodes; PGPR

\section{INTRODUCTION}

The control of pests and pathogens, including the soil-pathogenic nematodes is one of the most promising and challenging job in sustainable agriculture. The extent of diseases caused by the nematodes in agriculture systems observed by many researchers as has been evident in literature. Sharma et al. (1992) reported that nematodes caused about $20.6 \%$ losses in yield and total biomass production. However, for many years, the emphasis of nematode control has been on the use of synthetic pesticides, chemical fertilizers and resistant varieties of crop plants. The indiscriminate use of synthetic pesticides and chemical fertilizers to manage the plant-parasitic nematodes has resulted in environmental degradation and left harmful effects on human and cattle population, These show direct toxicity to predators, pollinators, fishes and humans (Pimentel 1981), pesticide resistance (Schmutterer 1981) and increased environmental and social costs. The excessive use of pesticides, leading to the contamination of the biosphere has created worldwide interest in pest control agents of plant origin which are easily available and biodegradable in nature. Mujahid and Gupta (2010) used organic manures to enhance the growth, yield and quality of lettuce.

Apart from harmful organisms, a number of beneficial microorganism also inhabit in the soil environment. Many species of soil bacteria are

*Author for correspondence: rose.amu@ gmail.com 
reported to promote plant growth by producing growth regulators, inducing root-exudation and enhancing the availability of nutrients to plant besides control of soil-borne plant pathogens (Weller 1988). Fluorescent pseudomonads have been shown to be potential agents for the biocontrol which suppressed the plant diseases by protecting the seeds and roots from fungal infection (Siddiqui et al. 2001) and overall plant growth from nematode infestation (Siddiqui and Mahmood 1999).

It is well established that the addition of organic additives increased the organic matter contents of the soil and availability of other plant nutrient (Brar et al. 2004) and subsequently increased the predaceous nature of rhizospheric population of microbes. Pseudomonas species are aggressive colonizers of the rhizosphere of various crop plants (Schroth and Hancock 1982) and have a broad spectrum antagonistic activity against plant pathogens. A number of organic additives of plant origin, including oil-seed cakes, chopped plant parts and seed dressing with plant extracts have been used as nematode control agents (Akhtar and Alam 1993; Tiyagi and Alam 1995). There is a need to investigate any role of oil-seed cakes for enhancing the population and activity of $P$. fluorescens for reducing the disease intensity of nematodes. With organic farming being pursued as the State Policy, the long term objective remains to evaluate different organic matters alone that are available widely, and in combination with plantgrowth promoting microorganisms to be used as a viable, sustainable, economic and eco-friendly alternative to the use of synthetic and hazardous chemicals.

Keeping in view the importance of organics, the present study was carried out to test the efficacy of oil-seed cakes of neem, castor, linseed, groundnut and sunflower in the presence and absence of $P$. fluorescens against the plant-parasitic nematodes infesting chickpea and their effect on plant-growth parameters of crop plant.

\section{MATERIALS AND METHODS}

\section{Preparation of Field and Sowing Schedule}

The experiment was conducted for two consecutive years, i.e., from 2008-2009 and 20092010. The nematode-infested experimental field at Agricultural Research Farm, Aligarh Muslim University was ploughed thoroughly and small beds measuring $6 \mathrm{~m}^{2}$ were prepared, leaving $0.5 \mathrm{~m}$ buffer zone between them. The soil was sandy loam in texture. The beds were treated with different oil-seed cakes of neem (A. indica), castor (R. communis), groundnut (A. hypogaea), linseed (L. usitatissimum), soybean (G. max) and sunflower(H.annuus) @ $110 \mathrm{~kg} \mathrm{~N} \mathrm{ha}{ }^{-1}$. Untreated beds served as control. Each treatment was replicated five times, arranged in randomized block design. The beds were immediately watered for the decomposition of oil-seed cakes and after ten days, bacterized seeds of chickpea (Cicer arietinum) cv. K-850 were sown. Weeding and watering were done whenever required during four month growing period.

\section{Experiment with Pseudomonas fluorescens}

Another experiment near to the first one on above lines was also laid out in the presence of $P$. fluorescens. Charcoal-soil based commercial cultures of fluorescent pseudomonads $\mathrm{GRP}_{3}$ was obtained from the Department of Microbiology, Indian Agricultural Research Institute, New Delhi. One hundred grams of culture of bacteria were suspended in $1000 \mathrm{ml}$ distilled water and $10 \mathrm{ml}$ (equivalent to $1 \mathrm{~g}$ of culture) were added around each seedling. One gram culture of $\mathrm{GRP}_{3}$ strain had $2.6 \times 10^{6}$ viable bacterial cells.

\section{Termination of Experiment and Measurement of Growth Parameters}

The experiments were terminated 120 days after the seed germination. Weight of shoots and roots were taken separately and the number of pods per plant were counted. The number of root-nodules per plant were also counted in the presence and absence of $P$. fluorescens. When the plants reached the flowering stage, the pollen fertility (percentage) was estimated by the method of Brown (1949), using stainability of pollen grains in $1 \%$ acetocarmine solution.

\section{Chlorophyll Estimation}

Chlorophyll content of leaves was estimated by the method of Hiscox and Israelstam (1979). One hundred milligrams of leaf pieces were placed in a vial containing $7.0 \mathrm{ml}$ dimethyl sulfoxide (DMSO) and the chlorophyll extracted by incubating for 60 minutes. The extract was transferred to a graduated tube and brought to $10 \mathrm{ml}$ with DMSO and assayed immediately. A sample of $3.0 \mathrm{ml}$ chlorophyll extract was transferred to a cuvette and the optical density values at 645 and $663 \mathrm{~nm}$ 
were read in a spectronic-1001 spectrophotometer against a DMSO blank.

\section{Extraction of Nematodes}

Before conducting the experiment simultaneously, the initial population of each of the nematodes were taken by the procedure as described by Southey (1986) to know the effect of $P$. fluorescens in combination with oil-seed cakes and also in untreated beds. The population of plantparasitic nematodes were determined from each bed before the treatment as well as after terminating the experiment by processing the soil sub-samples $(250 \mathrm{~g})$ by Cobb's sieving and decanting method along with Baermann funnel technique (Southey 1986). The nematodes were counted and identified. An average of five counts were taken in each case to determine the number of each nematode species. The number of rootgalls caused by $M$. incognita per plant were also counted.

\section{Statistical Analysis}

The data of the two years were pooled and the statistical analysis of the data for critical difference (C.D.) at $P=0.05$ and $P=0.01$ probability was done as per procedure described by Pansey and Sukhatme (1978).

\section{RESULTS}

\section{In the Absence of $P$. fluorescens}

Plant Growth Parameters

Significant improvements were observed in the plant weight, percent pollen fertility, pod numbers, number of root-nodules and chlorophyll content of chickpea in all the treatment as compared with the untreated control (Fig. 1). Maximum improvement was noticed in plant weight (72.48 g), pollen fertility (90.24\%), number of pods (65.74), number of root-nodules (47.7) and chlorophyll content $(3.326 \mathrm{mg} / \mathrm{g})$ in the beds treated with neem cake, compared with other oil-seed cakes and the untreated control. In the untreated control, plant weight $(23.92 \mathrm{~g})$, pollen fertility $(42.57 \%)$, number of pods (20.37), number of root-nodules (18.6) and chlorophyll content $(1.623 \mathrm{mg} / \mathrm{g})$ were reduced by the presence of plant-parasitic nematodes. However, significant increase were also noted in linseed cake, followed by soybean, sunflower, groundnut and castor cakes.

\section{Root-Galling}

The beds treated with oil-seed cakes exhibited a high reduction in the number of root-galls caused by $M$. incognita. The maximum reduction occurred in the beds treated with neem cake (Fig. 1). However, the reduction in the number of rootgalls were also noted in the beds treated with other oil-seed cakes. Although the reduction in rootgalling was statistically significant for other oilseed cakes.

\section{Population of Plant-Parasitic Nematodes}

The population of plant-parasitic nematodes increased beyond the initial level in untreated and treated beds with oil-seed cakes. $M$. incognita, $R$. reniformis and $T$. brassicae were the dominant species in all the beds (Fig. 2). The population of plant-parasitic nematodes increased from the initial level of 1286/250 g soil to 3087 in untreated beds, whereas treatments with oil-seed cakes reduced the nematode population. The maximum reduction occurred in neem cake treated beds (516), followed by linseed cake (614), sunflower cake (676), soybean cake (808), groundnut cake (875) and castor cake (953).

\section{In the Presence of $\boldsymbol{P}$. fluorescens \\ Plant Growth Parameters}

Significant improvements were noticed in the growth parameters such as plant weight, percent pollen fertility, pod numbers, number of rootnodules and chlorophyll content of chickpea in all the treatments as compared with the untreated control. The presence of $P$. fluorescens in all the beds showed greater increase in the growth parameters than in the absence of it. The maximum improvement was observed in plant weight $(95.39 \mathrm{~g})$, pollen fertility $(98.29 \%)$, number of pods (75.31), number of root-nodules (56.9) and chlorophyll content $(4.569 \mathrm{mg} / \mathrm{g})$ in the beds treated with neem cake compared to other oil-seed cakes treated beds. In untreated control, plant weight $(34.28 \mathrm{~g})$, pollen fertility $(55.87 \%)$, number of pods (26.57), number of root-nodules (24.5) and chlorophyll content $(2.023 \mathrm{mg} / \mathrm{g})$ were reduced by the presence of soil-nematodes. However, significant improvement was also noted in linseed, sunflower, soybean, groundnut and castor cakes (Fig. 1).

\section{Root-Galling}

Significant reduction in the number of root-galls was caused by $M$. incognita observed in the beds 
treated with oil-seed cakes (Fig. 1). The maximum reduction occurred in the beds treated with neem cake. However, reductions in the number of rootgalls were noted in the beds treated with other oil seed cakes. Untreated beds showed 100.2 rootgalls/plant while the neem cake reduced to 17.5 root-galls/plant (Fig. 1).

\section{Population of Plant-Parasitic Nematodes}

The population of soil-nematodes reduced in all the beds treated with oil-seed cakes along with $P$. fluorescens (Fig. 2). The population of the plantparasitic nematodes slightly increased from the initial level of $1286 / 250 \mathrm{~g}$ soil to 2288 in untreated beds, whereas the treatments with oil-seed cakes further reduced the nematode population. The maximum reduction occurred in neem cake treated beds (215), followed by linseed cake (295), sunflower cake (363), soybean cake (432), groundnut cake (500) and castor cake (572).
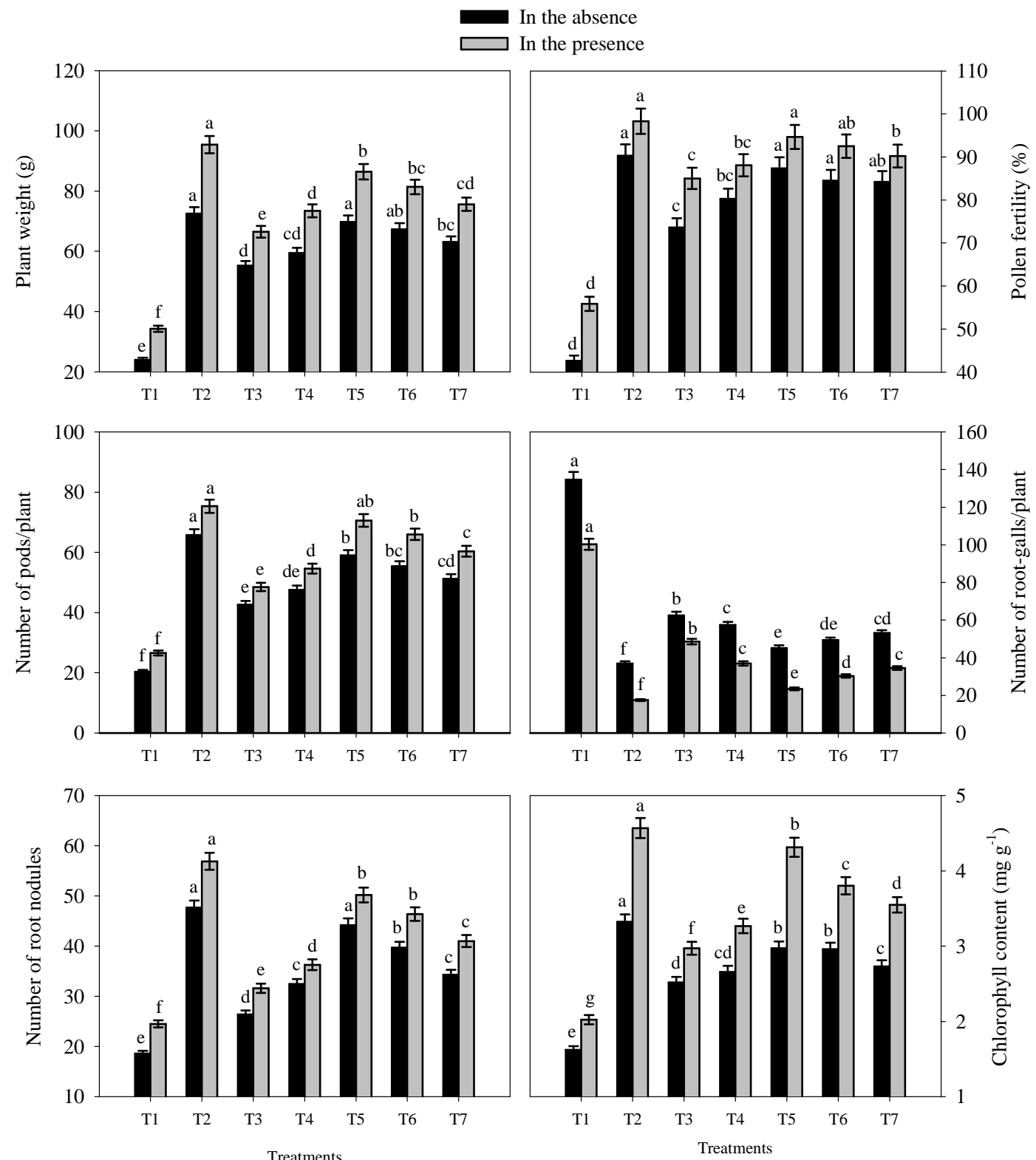

T1=Untreated, T2=Neem cake, T3=Castor cake, T4=Groundnut cake, T5=Linseed cake, T6=Sunflower cake, T7=Soybean cake

Figure 1 - Effect of oil-seed cakes in the absence and presence of Pseudomonas fluorescens on growth parameters of Chickpea. Values are Mean \pm SE. Data labelled by the same letters did not differ significantly at $P<0.05$. 


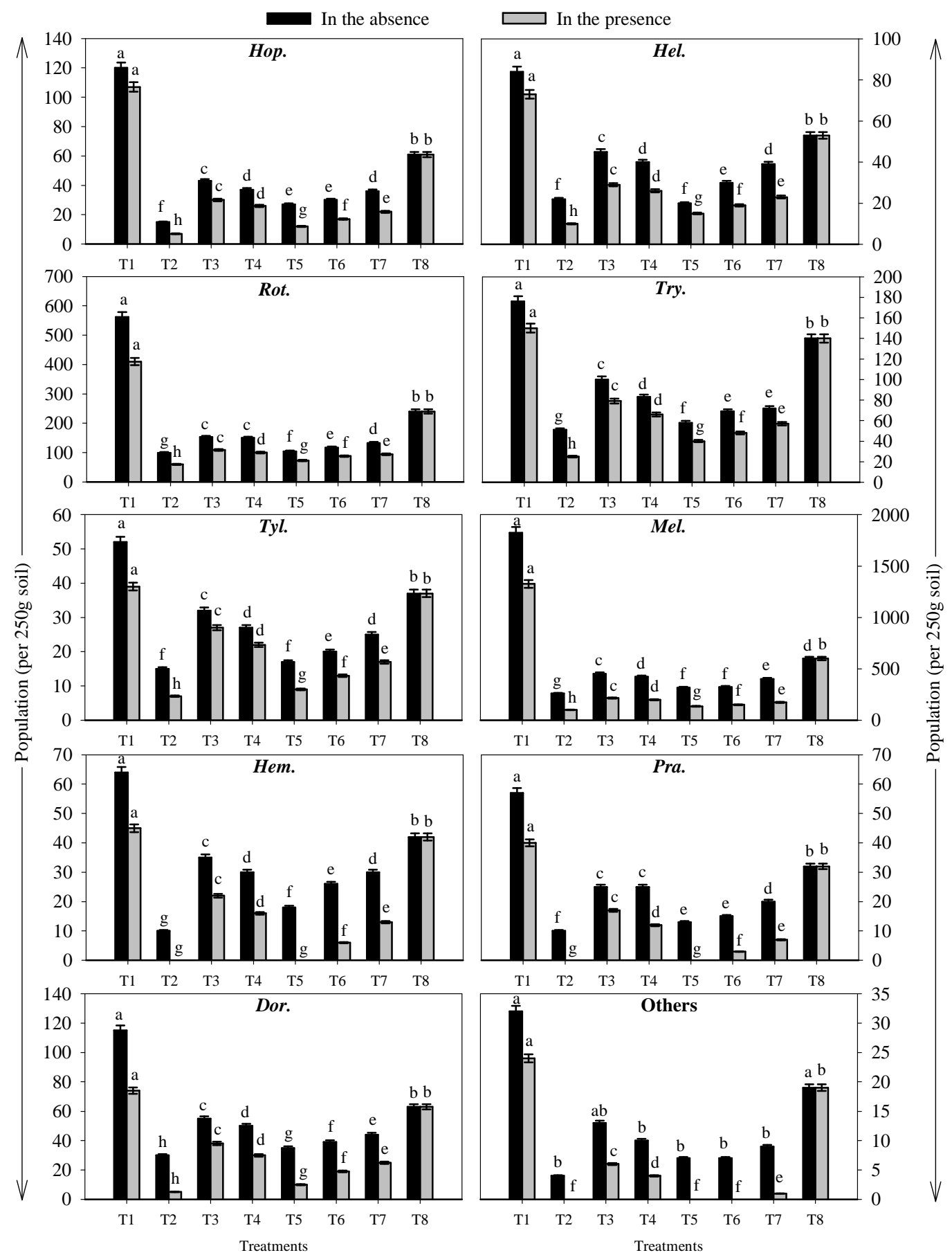

Hop. = Hoplolaimus indicus, Hel. = Helicotylenchus indicus, Rot. = Rotylenchulus reniformis, Try. = Tylenchorhynchus brassicae, Tyl. = Tylenchus filiformis, Mel. = Meloidogyne incognita, Dor. = Dorylaims viz. Longidorus elongatus, Xiphinema basiri and Trichodorus mirzai

$\mathrm{T} 1=$ Untreated, T2=Neem cake, T3=Castor cake, T4=Groundnut cake, T5=Linseed cake, T6=Sunflower cake, T7=Soybean cake, T8=Initial population

Figure 2 - Effect of oil-seed cakes in the absence and presence of Pseudomonas fluorescens on the population of plant-parasitic nematodes associated with Chickpea. Values are Mean \pm SE. Data labelled by the same letters did not differ significantly at $P<0.05$. 


\section{DISCUSSION}

In the present investigation, soil-application of oilseed cakes significantly reduced the population of plant-parasitic nematodes such as $M$. incognita, $R$. reniformis, T. brassicae, $H$. indicus, T. filiformis, $H$. mangiferae, etc. on chickpea. Root-knot development was also reduced by the oil-seed cake treatments. These findings confirmed those of Singh and Sitaramaiah (1970) and Tiyagi and Alam (1995) with several other crops. Neem cake, however reduced pathogenic nematodes beyond the threshold limit because of the presence of certain nematicidal compounds as has been reported earlier (Khan et al. 1974a, b).

Oil-cakes are generally rich in manurial ingredients such as nitrogen, phosphorus and potash. The application of these cakes into the soil takes about one or two weeks for decomposition. They have been found to be effective in moist soils than in dry soils. Various workers have carried out experiments on the efficacy of oil-seed cakes for controlling nematodes in tomato, eggplant, okra, chilli, cauliflower, cabbage (Goswami and Swarup 1971). Alam et al. (1980) claimed that these oilseed cakes significantly brought down the population of plant-parasitic nematodes and observed that the phenolic compounds released from oil-seed cakes reduced the nematode population in tomato. The oil-seed cakes amended soil were suggested to increase the resistance of tomato plants to $M$. javanica due to higher phenol content in their roots (Sitaramaiah and Singh 1978). It has been demonstrated that the application of oil-seed cakes to soil increased the predeceous activity of micro organisms in the soil and was more effective for controlling the population of nematodes (Southey 1986; Tiyagi et al. 2001). The addition of organic amendments or those enriched with micro-organisms somehow makes plant more tolerant or resistant to nematodes. Induced resistance in plants caused by the chemicals released from the micro-organisms was studied by Bostock (2005). Another factor which play an important role in nematode suppression in amended soils is soil structure. The present findings are in agreement with those of Queneherve and Chotte (1996) and the pores reduced nematode mobility (Otobe et al. 2004).

Among the many microbes occurring in the vicinity of roots, soil-bacteria are reported to promote the plant growth by producing the growth regulators, inducing root exudation. Some of these soil-bacteria such as Bacillus, Pseudomonas and Pantoee are also known to be suppressive to nematodes (Kokalis-Burelle et al. 2003; Mekete et al. 2009). Plant growth-promoting rhizobacteria are beneficial native soil bacteria that colonies the plant roots and results in increased plant-growth (Cleyet-Marcel et al. 2001). Similarly, the rhizobacterium P.fluorescens may also improve the plant growth by suppressing the pathogenic root pathogens (Oostendrop and Sikora 1989) through the production of biologically active substances (Gamliel and Katan 1993). Organic materials such as oil-seed cakes, compost, farmyard manure, green manures, crop residues and biofertilizers such as $P$. fluorescens are other valuable source of nutrients to improve the growth and ultimately the formation of root-nodules. The noticeable increase in root-nodulation was measured with the application of oil-seed cakes and $P$. fluorescens which might be due to rapid growth and proliferation of roots. The decomposition of oil-seed cakes could induce a deficiency in rhizospheric $\mathrm{N}$, thus causing a possible $\mathrm{N}$ hunger for the developing nodules. In contrast, the enrichment of rhizospheric $\mathrm{N}$ could stimulate nodule formation. Wei et al. (1996) revealed that some species of Pseudomonas caused greater colonization as well as greater siderophore production. Due to this, $P$. fluorescens caused a significant increase in chickpea plant and also a reduction in nematode population. The combined use of $P$. fluorescens with organic matters such as oil-seed cakes was better than the use of $P$. fluorescens alone for controlling the nematodes. Organic manuring results in several beneficial effects such as better soil structure which provides a more suitable medium for plant growth. The availability of nutrients may also be helpful for bacterial colonization of roots.

Organic materials decompose slowly, thereby protecting the crop (Daji and Iyengar 1971), hence their adverse effects on pathogens persist for longer duration. Economic considerations are important in commercial agriculture and the grower's acceptance of these strategies for controlling the plant-parasitic nematodes will involve practical considerations such as transportation costs, availability of organic waste materials and efficacy of treatment as compared to commercial nematicides which are totally discarded by farmers community because of their environmental hazards. P. fluorescens is one such proven biological agent which arrests the growth 
of pathogens and subsequently enhances the biomass production. The enhancement in plant growth and biomass production might be due to increased rate of photosynthesis and higher metabolic activities, mobilization of some movable forms of important nutrients, especially phosphorus, production of growth regulators and inhibition of soil-borne pathogens by $P$. fluorescens. Among such type of management practices, utilization of oil-seed cakes could improve the quality of the produce. Several research workers reported that originally produced crops were considered wholesome and valuable (Sankar et al. 2009) and sustained the soil fertility and crop growth.

\section{REFERENCES}

Akhtar M, Alam MM. Utilization of waste materials in nematodes control: a review. Biores Technol. 1993; 45: 1-7.

Alam MM, Ahmad M, Khan AM. Effect of organic amendments on the growth and chemical composition of tomato, eggplant and chilli and their susceptibility to attack by Meloidogyne incognita. Plant Soil. 1980; 57: 231-236.

Bostock RM. Signal crosstalk and induced resistance: straddling the line between cost and benefit. Ann Rev Phytopathol. 2005; 43: 545-580

Brar BS, Singh MV, Dhillon NS, Benipal DS. Soil quality, crop productivity and sustainable experiences under long-term maize-wheat-cowpea cropping. In: Inceptisols Research Bulletin. Ludhiana, Punjab: Department of Soil, Punjab Agricultural University; 2004. p. $1-90$

Brown GT. Pollen-slide Studies. USA: Spring field, Illinois; 1949.

Cleyet-Marcel JC, Larcher M, Bertrand H, Rapior S, Pinochet X. Plant growth enhancement by rhizobacteria. In: Morot-Gaudry JF, editor. Nitrogen Assimilation by Plants: Physiological, Biochemical and Molecular aspects. UK: Science Publishers Inc., Plymouth; 2001. p. 185-197.

Daji JA, Iyengar TR. Organic manures (others). In: Jaiswal et al. editor. Handbook of Manures and Fertilizers. New Delhi: I.C.A.R.; 1971. p. 68-122.

Gamliel A, Katan, J. Suppression of major and minor pathogens by fluorescent pseudomonads in solarized and non-solarized soil. Phytopathology. 1993; 83: 6875.

Goswami BK, Swarup G. Effect of oil-cake amended soil on the growth of tomato and root-knot nematode population. Indian Phytopathol. 1971; 24: 291-294.
Hiscox JD, Israelstam GF. A method for the extraction of chlorophyll from leaf tissue maceration. Can J Bot. 1979; 57: 1332-1334.

Khan MW, Alam MM, Khan AM, Saxena SK. Effect of water soluble fractions of oil-cakes and bitter principles of neem on some fungi and nematodes. Acta Bot Indica. 1974b; 2: 120-128.

Khan MW, Khan AM, Saxena SK. Rhizosphere fungi and nematodes of eggplant as influenced by oil-cake. Indian Phytopathol. 1974a; 27: 480-484.

Kokalis-Burelle N, Vavrina CS, Reddy MS, Kloepper JW. Amendment of muskmelon transplant media with plant growth-promoting rhizobacteria: effects on seedling quality, disease and nematode resistance. Hortechnology. 2003; 13: 476-482.

Mekete T, Hallmann J, Kiewnick S, Sikora RA. Endophytic bacteria from Ethopian coffee plants and their potential to antaginise Meloidogyne incognita. Nematology. 2009; 11: 117-127.

Mujahid AM, Gupta AJ. Effect of plant spacing, organic manures and inorganic fertilizers and their combinations on growth, yield and quality of lettuce (Lactuca sativa). Indian J Agric Sci. 2010; 80: 177181.

Oostendrop M, Sikora RA. Utilization of antagonistic rhizobacteria as seed treatment for the biological control of Heterodera schachtii in sugarbeet. Rev de Nematol. 1989; 12: 77-83.

Otobe K, Itou K, Mizukubo T. Micro-moulded substrates for the analysis of structure dependent behaviour of nematodes. Nematology. 2004; 6: 73-77.

Pansey VG, Sukhatme PV. Statistical Methods for Agricultural Workers. New Delhi: I.C.A.R.; 1978.

Pimentel D. An overview of integrated pest management. NY: Department of Ecology \& Systematics, Cornell University, Ithaca, Mimeo; 1981.p. 52.

Queneherve P, Chotte JL. Distribution of nematodes in vertisol aggregates under a permanent pasture in Martinique. Appl Soil Ecol. 1996; 4: 193-200.

Sankar V, Veeraragavathatham D, Kannan M. Effect of organic farming practices on post harvest storage life and organoleptic quality of yellow onion (Allium cepa). Indian J Agric Sci. 2009; 79: 608-614.

Schmutterer H. Ten years of neem research in the Federal Republic of Germany. In: Schmutterer H, Ascher KRS, Rembold H, editors. Natural Pesticides from the Neem tree (Azadirachta indica A. Juss). Germany: Eschborn; 1981. p. 21-51.

Schroth MN, Hancock JG. Disease-suppressive soil and root-colonizing bacteria. Science. 1982; 216: 1376-1381.

Sharma SB, Smith DH, McDonald D. Nematode constraints of chickpea and pigeonpea production in the semi-arid tropics. Plant Dis. 1992; 76: 868-874.

Siddiqui IA, Ehteshamul-Haque S, Shaukat SS. Use of rhizobacteria in the control of root-knot disease 
complex of mungbean. J Phytopathol. 2001; 149: 337-346.

Siddiqui ZA, Mahmood I. Role of bacteria in the management of plant-parasitic nematodes: a review. Biores Technol. 1999; 69: 167-169.

Singh RS, Sitaramaiah K. Control of plant-parasitic nematodes with organic soil amendments. PANS. 1970; 16: 287-297.

Sitaramaiah K, Singh RS. Effect of organic amendment on phenolic content of soil and plant response of Meloidogyne javanica and its host to related compounds. Plant Soil. 1978; 50: 671-679.

Southey JF. Laboratory methods for work with plant and soil nematodes. London: Ministry of Agriculture, Fisheries and Food, HMSO; 1986.

Tiyagi SA, Alam MM. Efficacy of oil-seed cakes against plant-parasitic nematodes and soil-inhabiting fungi on chickpea and mungbean. Biores Technol. 1995; $51: 233-239$.
Tiyagi SA, Khan AV, Alam MM. Role of oil-seed cakes for the management of plant-parasitic nematodes and soil-inhabiting fungi on lentil and mungbean. Arch Phytopathol Plant Prot. 2001; 33: 453-472.

Wei G, Kloepper JW, Tuzun S. Induced systemic resistance to cucumber diseases and increased plant growth by plant growth promoting rhizobacteria under field conditions. Phytopathology. 1996; 86: 221-224.

Weller DM. Biological control of soil borne plant pathogens in the rhizosphere with bacteria. Ann Rev Phytopathol. 1988; 26: 379-407.

Received: April 05, 2011; Revised: September 27, 2011; Accepted: September 04, 2012. 